\title{
Literature Review: Aktivitas Batang dan Daun Sambiloto (Andrographis Paniculata Nees) terhadap Target Molekular Terapi Diabetes
}

\section{Literature Review: The Activity of Sambiloto Stems and Leaves (Andrographis paniculata Nees) on Molecular Targets of Diabetes Therapy}

\author{
Nurul Hidayatul Mar'ah*, Rina Herowati, Gunawan Pamudji Widodo \\ Program Studi Pasca Sarjana, Fakultas Farmasi, Universitas Setia Budi \\ email: juanshine2013@gmail.com
}

(tanggal diterima: 14-09-2020, tanggal disetujui: 28-12-2020)

\section{INTISARI}

Andrographis paniculata Nees, disebut juga sambiloto adalah tanaman yang berkhasiat sebagai terapi alternatif diabetes melitus (DM). Sambiloto merupakan tanaman multi-compounds yang memiliki kandungan senyawa antara lain: diterpenoid, flavonoid dan polifenol. Studi ini bertujuan menjelaskan aktivitas senyawa kimia yang terkandung di dalam batang dan daun sambiloto terhadap lima target molekular terapi DM, yaitu Dipeptidyl Peptidase 4 (DPP4), Protein Tyrosine Phosphatase (PTP1B), $\alpha$-glukosidase, Glucose Transporter (GLUT) dan glukokinase.

Studi ini menggunakan metode systematic review, yakni dengan membuat PRISMA checklist dan diagram flow, menetapkan kriteria inklusi-eksklusi, search engine serta kata kunci untuk mendapatkan data yang relevan. Data yang diperoleh berupa hasil penelitian primer yang disajikan dalam tabel ekstraksi data, selanjutnya ditelaah secara komprehensif.

Hasil studi menunjukkan bahwa golongan senyawa diterpenoid dan flavonoid yang terkandung dalam batang dan daun sambiloto dapat memberikan aktivitas terhadap target molekular, seperti senyawa 19-trifenil isoandrografolid dapat menghambat DPP4, $\alpha$-glukosidase dan mengaktivasi glukokinase; senyawa andrografolakton dapat menghambat PTP1B; senyawa deoksiandrografolid meningkatkan translokasi dan akselerasi GLUT4; senyawa 15- $p$ metoksibenziliden 14-deoksi-11,12-didehidroandrografolid menghambat $\alpha$-glukosidase; dan Golongan flavonoid seperti senyawa apigenin mampu menghambat DPP4, PTP1B, serta mengaktivasi glukokinase.

Kata kunci : Andrographis paniculata; antidiabetes; target molekular.

\section{ABSTRACT}

Andrographis paniculata Nees, so-called sambiloto is a plant that is effective as an alternative therapy for diabetes mellitus (DM). Sambiloto is a multi-compound plant that contains diterpenoids, flavonoids and polyphenols. This study aims to explain the activity of chemical compounds contained in the stems and leaves of sambiloto against five molecular targets for DM therapy, namely Dipeptidyl Peptidase 4 (DPP4), Protein Tyrosine Phosphatase (PTP1B), $\alpha$-glucosidase, Glucose Transporter (GLUT) and glucokinase.

This study used a systematic review method by making PRISMA checklists and flow diagrams, determining inclusion-exclusion criteria, search engines and keywords to get relevant data. The data was obtained from the primary research results presented in the data extraction table, and then was analyzed comprehensively.

The results of the study were: the diterpenoids and flavonoids provided activity against molecular targets, such as 19-triphenyl isoandrographolide which inhibited DPP4, $\alpha$-glucosidase and activated glucokinase; andrographolactone inhibited PTP1B; deoxyandrographolide increased translocation and acceleration of GLUT4; 15- $p$-methoxybenziliden 14-deoxy-11,12didehydroandrographolide inhibited $\alpha$-glukosidase; and flavonoid groups such as apigenin compounds inhibited DPP4, PTP1B, and activated glucokinase.

Key words: Andrographis paniculata; antidiabetic; molecular target. 


\section{PENDAHULUAN}

Penyakit Diabetes Melitus (DM) merupakan suatu gangguan metabolisme karbohidrat, lemak dan protein yang ditandai dengan hiperglikemia akibat penurunan sekresi insulin, kerja insulin atau keduanya [1]. Prevalensi berdasarkan International Diabetes Federation (IDF) diperkirakan 1,1 juta anak-anak dan remaja berusia 14-19 tahun memiliki DM maka tanpa intervensi terhadap peningkatan ini, maka akan ada setidaknya 629 juta orang yang hidup dengan diabetes pada tahun 2045 [2]. Terapi DM jangka panjang menggunakan obat-obat terapi lini pertama dan kedua dapat menimbulkan efek samping dan kontra indikasi yang dapat memperburuk kondisi pasien DM [3], sehingga dilakukan studi pendekatan terhadap tanaman herbal yang dapat menjadi alternafif dalam terapi DM, yaitu tanaman sambiloto (Andrographis paniculata Nees). Sambiloto disebut sebagai tanaman multi-compounds karena mengandung berbagai macam senyawa berkhasiat seperti diterpenoid, flavonoid dan polifenol [4].

Beberapa target molekular yang memiliki peran dalam patofisiologi DM antara lain: DPP4, PTP1B, $\alpha$-glukosidase, GLUT dan glukokinase. DPP4 merupakan enzim penghidrolisis Glukagon-Like Peptide-1 (GLP1) suatu hormon insulinotropik yaitu menstimulasi sekresi insulin, menghambat glukagon serta menghambat pengosongan lambung [5]. Penghambatan DPP4 akan meningkatkan kadar GLP1 dengan potensi antidiabetes. PTP1B memodulasi jalur insulin dan leptin secara negatif, dan saat PTP1B dihambat akan memperkuat fosforilasi reseptor insulinsubstrat sehingga sel insulin lebih responsif [6]. $\alpha$-glucosidase adalah kategori enzim glikosida hidrolase yang dapat melepaskan ikatan glikosidik dari substrat sehingga mampu memecah glikogen dan menyebabkan peningkatan penyerapan karbohidrat. Penghambatannya akan mengakibatkan penurunan penyerapan karbohidrat dan gula [6]. GLUT adalah sekelompok protein yang berfungsi membawa glukosa dari ruang ekstraseluler menuju intraseluler bertujuan memasok kebutuhan energi dalam metabolisme [7]. Sebagai contoh GLUT 4 yang memiliki lokasi ekspresi jaringan pada otot, adipose dan hati, serta salah satu substrat yang dapat berkomplemen adalah glukosa [8]. Glukokinase adalah anggota dari enzim hexokinase yang merupakan katalisator pertama dalam proses glikolisis dan fosforilasi glukosa menjadi glukosa 6-fosfat. Dalam sel-sel pankreas, glukokinase merupakan enzim yang membatasi laju metabolisme glukosa dan menentukan laju sekresi insulin [9]. Studi ini bertujuan untuk mengetahui mekanisme ativitas daun dan batang sambiloto terhadap kelima target molekular tersebut.

\section{METODE PENELITIAN}

Metode yang digunakan adalah systematic review yakni dengan membuat PRISMA checklist dan diagram flow, menetapkan kriteria inklusi-eksklusi, search engine serta kata kunci pencarian artikel penelitian. Hal tersebut bertujuan untuk memberikan tuntunan dalam melakukan review dan memberikan batas pencarian terhadap artikel penelitian yang relevan. Data yang diperoleh berupa hasil penelitian primer, tersaji dalam tabel ekstraksi data yang memuat judul, subjek, 
parameter, metode dan hasil penelitian, kemudian data dianalisis secara komprehensif.

\section{HASIL DAN PEMBAHASAN}

\subsection{HASIL}

Lebih dari 150 artikel dalam penelitian ini yang dilakukan identifikasi awal dan ditetapkan 113 artikel untuk dilakukan sortirisasi. Dari 113 artikel tersebut kemudian dilakukan skrining dan muncul 27 jurnal yang diekslusikan, sisanya dilakukan kajian secara full text untuk memperoleh artikel yang layak dari aspek abstrak, latar belakang, metode, hasil, pembahasan sampai kesimpulan. Dari sejumlah artikel tersebut masih dilakukan penilaian akhir dengan lebih seksama dan terpilih 10 artikel untuk masuk ke dalam ekstraksi data. Data ekstraksi tersebut mencangkup aktivitas Sambiloto terhadap target molekular DPP4, $\alpha$-glukosidase, GLUT, glukokinase dan PTP1B.

3.1.1. Aktivitas Sambiloto terhadap Target Molekular DPP4. Ekstrak etanol herba Andrographis paniculata (Burm.f.) Wall. Ex Nees) dilakukan uji secara in vitro dengan metode reaksi enzimatik pada inkubasi suhu $37^{\circ} \mathrm{C}$, menggunakan substrat Gly-Pro-p-nitroanilid (GPPN) yang terhidrolisis menghasilkan produk paranitroanilid (pNA). pNA berwarna kuning yang kemudian absorbansi dibaca pada $380 \mathrm{~nm}$, dan diperoleh hasil pada dosis 2,5 $\mathrm{g} / \mathrm{ml}$ dapat menghambat DPP4 dengan persentase penghambatan 37,03 \%. Nilai ini masih cukup lemah jika dibandingkan dengan aktivitas kontrol positif sitagliptin yang memiliki persentase penghambatan mencapai 74,77 [10]. Secara in vitro juga dilakukan uji pada ekstrak air dan methanol Andrographis paniculata dengan metode reaksi enzimatik dengan substrat p-nitrophenyl phosphate (pNPP). Produk dibaca dalam bentuk p-nitrofenol pada suhu $37^{\circ} \mathrm{C}$ dan panjang gelombang $405 \mathrm{~nm}$. Dosis $25 \mu \mathrm{g} / \mathrm{ml}$ ekstrak air dan metanol Andrographis paniculata memberikan nilai penghambatan masing-masing $40,00 \pm 11,5 \%$ dan $74,80 \pm 1,90 \%$ dengan IC $5013,40 \mu \mathrm{g} / \mathrm{ml}$. Nilai tersebut tidak lebih kuat dibandingkan dengan kontrol positif RK-682 yang memiliki penghambatan $84.0 \pm 1.5 \%$ dan IC50 $2.05 \mu \mathrm{g} / \mathrm{ml}$ [11].

3.1.2. Aktivitas Sambiloto terhadap Target Molekular $\alpha$-Glukosidase. Aktivitas penghambatan terhadap $\alpha$-glukosidase ditunjukkan oleh analog senyawa diterpenoid dari ekstrak Andrographis paniculata menggunakan metode reaksi enzimatik dengan substrat. Penghambatan diamati pada suhu $37^{\circ} \mathrm{C}$ dan absorbansi dibaca pada $405 \mathrm{~nm}$. Secara in vitro senyawa 14-deoksi-11, 12didehidroandrografolid memiliki aktivitas penghambatan 16,5 \%. Senyawa 15-pmetoksilbenziliden 14-deoksi-11, 12-didehidroandrografolid dapat menghambat enzim $\alpha$-glukosidase mencapai $100 \%$ dengan nilai IC50 $16 \mu \mathrm{M}$ dengan penambahan substituen pada $\mathrm{C}-15\left(\mathrm{R}^{1}=\mathrm{H}, \mathrm{R}^{2}=4-\mathrm{MeOC}_{6} \mathrm{H}\right)$ [12]. Aktivitas penghambatan juga ditunjukkan pada ekstrak etanol daun Andrographis paniculata dan senyawa andrografolid dengan parameter IC $_{50}$, PBG, AUC. Secara in vitro dengan reaksi enzimatik dengan substrat p-Nitrophenyl- $\alpha$-D-glucopyranocid dan pembacaan absorbansi pada $405 \mathrm{~nm}$ menunjukkan bahwa ekstrak Andrographis paniculata dan andrografolid dapat menghambat terhadap $\alpha$-glukosidase dengan IC50 masing- 
masing 17,2 mg dan 11,0 mg. Nilai tersebut masih dianggap belum cukup kuat jika dibandingkan dengan nilai IC50 kontrol positif acarbose yaitu 6,2 mg. Metode secara in vivo juga dilakukan dengan pemberian sampel kepada hewan uji tikus yang telah diinduksi STZ, kemudian dilakukan sampling darah dan tes toleransi karbohidrat sehingga dapat menghitung penurunan PBG dan AUC. Pemberian konsentrasi 500 dan $1000 \mathrm{mg} / \mathrm{kg}$ ekstrak etanol daun Andrographis paniculata dan $10 \mathrm{mg} / \mathrm{kg}$ andrografolid menyebabkan penurunan PBG dan AUC bernilai signifikan $(\mathrm{P}<0,05)$ [13]. Penelitian secara in vivo menggunakan ekstrak etanol Andrographis paniculata (Burm.f.) juga telah dilakukan sebelumnya terhadap hewan uji yang diinduksi STZ terhadap toleransi karbohidrat (pati, sukrosa, glukosa) selanjutnya dihitung penurunan PBG dan AUC. Pada tes toleransi pati, ekstrak Andrographis paniculata dengan dosis 500 dan $1000 \mathrm{mg} / \mathrm{kg}$ secara signifikan menurunkan PBG dan hanya dosis $1000 \mathrm{mg} / \mathrm{kg}$ yang secara signifikan menurunkan AUC pada tikus diabetes. Pada tes toleransi sukrosa, dengan dosis $1000 \mathrm{mg} / \mathrm{kg}$ saja yang secara signifikan mampu menurunkan PBG dan AUC pada tikus diabetes. Pada tes toleransi glukosa, ekstrak Andrographis paniculata gagal menurunkan PBG dan AUC pada tikus diabetes [14].

3.1.3. Aktivitas Sambiloto terhadap Target Molekular GLUT. Pemberian sampel fraksi kloroform dari ekstrak daun Andrographis paniculata dengan dosis $200 \mathrm{mg} / \mathrm{kg}$ secara oral kepada hewan uji tikus yang telah diinduksi STZ, kemudian dilakukan analisa RT-PCR terhadap ekspresi m-RNA glukokinase dan GLUT4, menunjukkan bahwa fraksi tersebut dapat meningkatkan kadar glukokinase di hati dan beberapa profil ekspresi enzim glukoneogenik, glukosa-6fosfat dan fosfoenol piruvat karboksikinase (PEPCK) secara signifikan yakni hampir dua kali lipat dibandingkan kontrol diabetes. Selain itu ekspresi m-RNA GLUT4 pada jaringan otot dan adiposa juga terjadi akselerasi atau penambahan jumlah [15]. Penelitian lain juga dilakukan menggunakan deoksiandrografolid yakni senyawa natural Andrographis paniculata baik secara in vitro maupun in vivo. Parameter yang diamati secara in vitro adalah peningkatan jumlah permukaan GLUT4 dilihat dari lipatan terhadap kontrol basal, sedangkan in vivo adalah kadar gula darah dan AUC. Metode in vitro dilakukan dengan menggunakan sel L6-GLUT4myc, mengamati peningkatan level/jumlah transporter (GLUT dan GLUT4) dan dianalisis menggunakan teknik western blot, serta mengamati translokasi dan redistribusi GLUT4 ke permukaan sel dengan uji pasangan antibodi secara colorimetrik. Metode in vivo dilakukan dengan pemberian sampel kepada hewan uji yang diinduksi STZ, kemudian dilakukan sampling darah untuk menghitung penurunan kadar gula darah. Hasil menunjukkan deoksiandrografolid secara signifikan mampu meningkatkan translokasi dan redistribusi GLUT4 ke permukaan sel dan menurunkan kadar gula darah serta meningkatkan toleransi glukosa [16].

3.1.4. Aktivitas Sambiloto terhadap Target Molekular Glukokinase. Uji aktivitas terhadap glukokinase dilakukan menggunakan andrografolid murni, ekstrak etanol batang dan daun Andrographis paniculata secara in vivo. Sampel diberikan kepada hewan uji yang diinduksi nikotinamid dan STZ, 2 kali sehari selama 21 hari, kemudian dilakukan analisa jaringan hati untuk melihat aktivitas 
enzim. Andrografolid $10 \mathrm{mg} / \mathrm{kg}$ menunjukkan peningkatan signifikan aktivitas GK, HK dan diikuti penurunan glukosa-6fosfat yang signifikan pula. Sedangkan pada ekstrak etanol Andrographis panicalata, peningkatan GK secara signifikan pada dosis $1000 \mathrm{mg} / \mathrm{kg}$ [17].

3.1.5. Aktivitas Sambiloto terhadap Target Molekular PTP1B. Aktivitas PTP1B diamati menggunakan parameter afinitas pengikatan ligan-protein/enzim dengan metode docking molekular, yakni menggunakan 19 senyawa kimia yang diperoleh dari PubChem databases docking molecular, dilakukan menggunakan AutoDock Vina in PyRx, dan hasil menunjukkan bahwa apigenin memiliki afinitas ikatan terhadap PTP1B, DPP4 dan glukokinase dengan nilai masing-masing -8,50, 8,60, dan -8,90. Selain itu, senyawa 19-trifenil andrografolid juga memiliki afinitas pengikatan terhadap DPP4, $\alpha$-glukosidase dan glukokinase dengan nilai masingmasing -9,33, -8,75 dan -10,4, kcal/mol [18].

\subsection{PEMBAHASAN}

Studi [10] melakukan uji aktivitas ekstrak etanol herba Andrographis paniculata menggunakan metode in vitro yakni melakukan reaksi enzimatik dengan substrat Gly-pro-p-nitroanilid (GPPN) dan menunjukkan adanya aktivitas penghambatan ekstrak terhadap target molekular DPP4 namun nilainya cenderung lemah dibandingkan kontrol positif sitagliptin. Sampel yang digunakan berupa ekstrak sehingga tidak dapat dinyatakan secara jelas bagian senyawa mana yang beraktivitas, akan tetapi studi [18] melalui metode docking molekular memberikan gambaran bahwa senyawa golongan diterpenoid terkandung dalam sambiloto yakni 19-trifenil andrografolid memberikan afinitas ikatan terhadap protein DPP4. Sisi aktif enzim DPP4 dibagi menjadi beberapa sub wilayah: catalytic triad (Ser630, Asp708, His740), rongga oxyanion (Tyr47, Ser631), wilayah dengan residu jembatan garam (Glu205, Glu206, Tyr662) dan kantong S1 and S2 yang berisi (Arg125, Ser209, Phe357, Arg358, Tyr547, Ser631, Val656, Trp659, Tyr62, Tyr666, Asn710, Val711) [19]. Senyawa 19-trifenil isoandrografolid menunjukkan memiliki afinitas ikatan terbaik sebagaimana ligan asli yang mampu berinteraksi dengan sisi aktif enzim, yakni dengan residu asam amino Tyr662, Tyr666, Glu205, Glu206 dan Arg125. Karakteristik penting dari ligan senyawa 19-trifenil isoandrografolid yang memberikan interaksi adalah donor dan akseptor ikatan hidrogen yang masingmasing berjumlah satu dan lima.

Aktivitas penghambatan PTP1B ini ditunjukkan oleh studi [11] secara in vitro dengan metode reaksi enzimatik dengan substrat p-nitrofenil fosfat (pNPP). Ekstrak air dan metanol Andrographis paniculata mampu memberikan efek penghambatan terhadap enzim PTP1B dengan kategori lemah, namun studi [18] memberikan gambaran bagaimana senyawa andrografolakton menunjukkan nilai afinitas ikatan terbaik dalam penghambatan $(-9,45 \pm 0,06)$. Senyawa tersebut mampu berikatan terhadap residu asam amino Gln266, Gly220, Phe182, Gly218, Ile219, Try46, Val49, Ala217, Ser216 dan Arg221 pada sisi aktif enzim PTP1B. Secara ideal rancangan mimetik PTyr yang dapat memberikan penghambatan yang kuat terhadap enzim PTP1B yakni memiliki gugus peptida, gugus karboksilat serta gugus fofat yang tidak terhidrolisis [20]. Selain itu sifat hidrofilik pada sisi aktif enzim menyebabkan lebih 
menyukai senyawa dengan gugus hidrofilik walaupun gugus hidrofobik juga masih dapat memberikan interaksi. Andrografolakton dianggap memiliki sebagian karakteristik mimetik PTyr yang mampu memberikan interaksi terhadap enzim PTP1B sebagai inhibitor. PTP1B adalah target molekular satu situs dengan PTPs dimana mimetik pTyr dalam menghambat PTPs adalah elemen kunci pengembangan senyawa. Pengembangan analog pTyr seperti dengan mengganti gugus fosfat menjadi gugus metil fosfonat, mengkompensasi penurunan elektronegativitas dari perubahan $\mathrm{O}$ menjadi $\mathrm{C}$, dapat mengikat sisi aktif PTPs tanpa terhirolisis [21], maka modifikasi senyawa dirasa perlu untuk memperoleh efek penghambatan yang lebih baik.

Tiga studi [12], [13] dan [14] telah melakukan uji aktivitas penghambatan senyawa diterpenoid sambiloto terhadap $\alpha$-glukosidase. Ketiganya dilakukan secara in vitro melalui reaksi ezimatik dengan substrat p-nitrofenil- $\alpha$-Dglukopiranosid (pNPG). Senyawa andrografolid serta analog dan derivatnya terbukti poten dalam menghambat enzim $\alpha$-glukosidase. Aktivitas tersebut dapat ditingkatkan dengan menurunkan beberapa analog dan derivat yang lebih spesifik sifatnya serta dengan memodifikasi beberapa struktur seperti 15-pmetoksilbenziliden14-deoksi-11,12-didehidroandrografolid. Senyawa tersebut adalah derivat alami dari andrografolid yang meningkat penghambatannya saat dilakukan pengurangan ikatan olefin C 12, 13. Aktivitas hambat senyawa diterpenoid terhadap $\alpha$-glukosidase diperkuat dengan uji in vivo yang dilakukan dengan tes karbohidrat terhadap tikus yang telah diinduksi streptozotocin (STZ), menunjukkan penurunan kadar gula darah dan AUC yang signifikan. Sisi aktif enzim

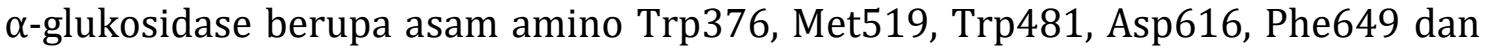
Arg600 yang mampu berinteraksi dengan ligan senyawa. Interaksi tersebut ditunjukkan adanya ikatan yang kuat terhadap senyawa 19-trifenil isoandrografolid. Struktur ligan senyawa yang memberikan pengaruh penting dalam penghambatan enzim ini adalah adanya gugus hidroksil fenol. Gugus ini mampu memberikan afinitas ikatan yang kuat dan minim efek samping sehingga sangat bermanfaat secara farmakologis. Senyawa apigenin yang terkandung pula dalam sambiloto, juga memberikan potensi penghambatan karena adanya gugus hidroksil fenol. Pentingnya gugus ini dalam penghambatan $\alpha$-glukosidase juga ditunjukkan pada senyawa flavonoid hesperetin yang memiliki tiga gugus hidroksil fenol [22].

Studi [16] menggunakan senyawa deoksiandrografolid dalam uji aktivitas terhadap target molekular GLUT. Uji dilakukan dengan menghitung peningkatan jumlah transporter (GLUT1 dan GLUT4) dan translokasi GLUT4 ke permukaan sel. Secara in vitro, deoksiandrografolid mampu meningkatkan translokasi dan redistribusi GLUT4 ke membran sel secara signifikan, namun tidak pada peningkatan jumlah transporternya. Peningkatan parameter tersebut dikuatkan dengan perlakuan in vivo dimana deoksiandrografolid secara signifikan mampu menurunkan kadar gula darah dan meningkatkan toleransi glukosa. Hal ini relevan dengan studi [15] yang menyatakan peningkatan akselerasi m-RNA GLUT4 pada jaringan otot dan adiposa setelah pemberian fraksi kloroform sambiloto pada tikus 
dengan dosis $200 \mathrm{mg} / \mathrm{kg}$. GLUT4 memiliki sisi aktif pengikatan substrat yaitu berupa kutub residu Gln280, Gln281, Asn315 dan Glu378 [23], namun sisi aktif ini berfungsi mengikat substrat polar berupa glukosa untuk ditransfer ke dalam sel. Senyawa deoksiandrografolid dalam sambiloto mampu meningkatkan translokasi GLUT4 dengan mekanisme kerja secara tidak langsung, yaitu kedua senyawa yang memiliki sebagian kriteria mimetik PTyr bekerja menghambat PTP1B dan mampu menstimulasi terjadinya fosforilasi IRS1, mengaktifkan PI3K dan Akt. Hal ini menyebabkan fosforilasi AMPK dan peningkatan translokasi GLUT4 ke membran sel. Dengan kata lain senyawa andrografolakton yang sebelumnya dinyatakan sebagai penghambat PTP1B juga mampu meningkatkan translokasi GLUT4.

Pengamatan terhadap aktivitas glukokinase dilaporkan menggunakan senyawa andrografolid murni dan ektrak etanol batang dan daun Andrographis paniculata dengan metode in vivo [17]. Kedua Subjek memiliki nilai aktivitas mengaktivasi glukokinase yang signifikan, andrografolid pada dosis $10 \mathrm{mg} / \mathrm{kg}$ dan ekstrak pada dosis $1000 \mathrm{mg} / \mathrm{kg}$. Selain heksokinase, glukokinase diketahui sebagai enzim yang juga berperan dalam penghambatan proses glikolisis yakni pada tahap pembentukan glukosa-6fosfat. Hasil docking molekuler [18] juga menyatakan senyawa 19-trifenil isoandrografolid memiliki afinitas pengikatan yang baik terhadap protein glukokinase. Kombinasi kedua metode pada studi tersebut saling menguatkan akan aktivitas senyawa diterpenoid yang terkandung di dalam batang dan daun sambiloto. Interaksi ligan senyawa 19-trifenil isoandrografolid ini terjadi pada sisi aktif enzim glukokinase yaitu Met235, leu451, Arg63 dan Gln98. Senyawa apigenin juga memiliki afinitas interaksi yang sama terhadap glukokinase namun nilainya tidak lebih kuat. Fitur umum yang dimiliki senyawa aktivator glukokinase ini adalah adanya akseptor donor ikatan hidrogen, dan kriteria tersebut dimiliki senyawa 19-trifenil isoandrografolid. Selain itu dua ikatan hidrogen dengan punggung gugus $\mathrm{NH}$ dan $\mathrm{CO}$ akan mengikat Arg63 [23] sehingga menghasilkan aktivasi enzim glukokinase.

Berdasarkan uraian tersebut menunjukkan bahwa senyawa golongan diterpenoid dan flavonoid yang terkandung di dalam sambiloto dapat memberikan aktivitas terhadap lima target molekular yang berperan dalam patofisiologi DM. Diketahui kedua golongan senyawa tersebut banyak terkandung di dalam batang maupun daun sambiloto, khususnya diterpenoid [24].

\section{KESIMPULAN}

Berdasarkan kajian, hasil penelitian eksperimental menunjukkan bahwa senyawa dalam ekstrak etanol Andrographis paniculata mampu menghambat DPP4 walau sifatnya lemah, dan secara kuat menghambat $\alpha$-glukosidase serta meningkatkan akselerasi m-RNA dari GLUT4. Sedangkan ekstrak air dan metanolnya secara lemah menghambat PTP1B. Beberapa senyawa diterpenoid terkandung dalam Andrographis paniculata yang terbukti memiliki aktivitas adalah 14-deoksi-11, 12 didehidroandrografolid dan 15-p-metoksilbenziliden 14-deoksi, 12-didehidroandrografolid yang secara kuat menghambat $\alpha$-glukosidase, serta senyawa dioksiandrografolid yang mampu meningkatkan translokasi GLUT4. Sedangkan hasil penelitian docking molecular menunjukkan senyawa 19-trifenil 
isoandrografolid dapat menghambat DPP4, $\alpha$-glukosidase dan mengaktivasi glukokinase, senyawa andrografolakton dapat menghambat PTP1B, dan senyawa apigenin mampu menghambat DPP4, PTP1B, serta mengaktivasi glukokinase, dimana hal ini tetap membutuhkan pembuktian eksperimental baik secara in vitro maupun in vivo.

\section{UCAPAN TERIMAKASIH}

Terima kasih kepada segenap civitas Program Studi Pasca Sarjana Farmasi, Fakultas Farmasi, Universitas Setia Budi Surakarta.

\section{DAFTAR PUSTAKA}

[1]. Alberti, K. G. M. M., \& Zimmet, P. Z. (1998). Definition, Diagnosis and Classification of Diabetes Mellitus and its Complications Part 1: Diagnosis and Classification of Diabetes Mellitus Provisional Report of a WHO Consultation. Diabetic Medicine, 15: 539-553.

[2]. W. H. 0. (2019). Classification of Diabetes Mellitus 2019. World Health Organization.https://apps.who.int/iris/bitstream/handle/10665/325182/9 789241515702-eng.pdf.

[3]. Boyle, D. I. R., Evans, J. M. M., Sullivan, F., \& Morris, A. D. (2001). Contraindications to metformin therapy in patients with Type 2 diabetes population-based study of adherence to prescribing guidelines, (18): 483488. https://doi.org/10.1046/j.1464-5491.2001.00509.x.

[4]. Rao, Y. K., Vimalamma, G., Rao, C. V., \& Tzeng, Y. (2004). Flavonoids and andrographolides from Andrographis paniculata. Phytochemistry, 65: 23172321. https://doi.org/10.1016/j.phytochem.2004.05.008.

[5]. Deacon, C. F., \& Holst, J. J. (2006). Dipeptidyl peptidase IV inhibitors: A promising new therapeutic approach for the management of type 2 diabetes. International Journal of Biochemistry and Cell Biology, 38(5-6): 831-844. https://doi.org/10.1016/j.biocel.2005.09.011.

[6]. Kerru, N., Singh-Pillay, A., Awolade, P., \& Singh, P. (2018). Current anti-diabetic agents and their molecular targets: A review. European Journal of Medicinal Chemistry, 152: 436-488. https://doi.org/10.1016/j.ejmech.2018.04.061.

[7]. Mccall, A. L. (2019). Glucose Transport. Stress: Physiology, Biochemistry, and Pathology. Elsevier Inc. https://doi.org/10.1016/B978-0-12-8131466.00022-9.

[8]. Gauer, J. S., Tumova, S., Lippiat, J. D., Kerimi, A., \& Williamson, G. (2018). Differential patterns of inhibition of the sugar transporters GLUT2, GLUT5 and GLUT7 by flavonoids. Biochemical Pharmacology, 152(3): 11-20. https://doi.org/10.1016/j.bcp.2018.03.011.

[9]. Efanov, A. M., Barrett, D. G., Brenner, M. B., Briggs, S. L., Delaunois, A., Durbin, J. D., \& Gromada, J. (2005). A Novel Glucokinase Activator Modulate Pancreatic Islet and Hepatocyte Function. Endocrinology, 146(9): 3696-3701. https://doi.org/10.1210/en.2005-0377. 
[10]. Riyanti, S., Suganda, A. G., \& Sukandar, E. Y. (2016). Dipeptidyl Peptidase-IV Inhibitory Activity of Some Indonesian Medical Plants. Asian Journal of Pharmaceutical and Clinical Research, 9(2): 2-4.

[11]. Saifudin, A., Kadota, S., \& Tezuka, Y. (2012). Protein tyrosine phosphatase 1B inhibitory activity of Indonesian herbal medicines and constituents of Cinnamomum burmannii and Zingiber aromaticum. J. Nat. Med., 67, (5): 264270. https://doi.org/10.1007/s11418-012-0674-7.

[12]. Dai, G., Xu, H., Wang, J., Liu, F., \& Liu, H. (2006). Studies on the novel a glucosidase inhibitory activity and structure activity relationships for andrographolide analogues. Bioorganic \& Medicinal Chemistry Letters, 16, 16: 2710-2713. https://doi.org/10.1016/j.bmcl.2006.02.011.

[13]. Subramanian R., M. Zaini Asmawi, \& Amirin Sadikun. (2008). In vitro $\alpha$ glucosidase and $\alpha$-amylase enzyme inhibitory effects of Andrographis paniculata extract and andrographolide. Acta Biochimica Polonica, 55(2): 391398. DOI: https://doi.org/10.18388/abp.2008_3087.

[14]. Subramanian, R., \& Asmawi, M. Z. (2006). Inhibition of a -Glucosidase by Andrographis paniculata Ethanol Extract in Rats. Pharmaceutical Biology, 44(8): 600-606. https://doi.org/10.1080/13880200600896892.

[15]. Kharya, M. D. (2012). Glucose metabolism and diabetogenic gene expression analysis of chloroform fraction of Andrographis paniculata ( Nees ) whole herb in diabetic albino mice expression analysis of chloroform fraction of diabetic albino mice. Journal of Complementary and Integrative Medicine, 9(1): 1-16. https://doi.org/10.1515/1553-3840.1632.

[16]. Arha, D., Pandeti, S., Mishra, A., \& Prakash, S. (2015). Deoxyandrographolide promotes glucose uptake through glucose transporter-4 translocation to plasma membrane in L6 myotubes and exerts antihyperglycemic effect in vivo. European Journal of Pharmacology, 768: 207-216. https://doi.org/10.1016/j.ejphar.2015.10.055.

[17]. Subramanian, R., Asmawi, M. Z., \& Sadikun, A. (2008). Effect of Andrographolide and Ethanol Extract of Andrographis paniculata on Liver Glycolytic , Gluconeogenic , and Lipogenic Enzymes in a Type 2 Diabetic Rat Model. Pharmaceutical Biology, 46(11): 772-780. https://doi.org/10.1080/13880200802316079.

[18]. Julaiha, Widodo, G. P., \& Herowati, R. (2019). Predicting ADME and Molecular Docking Analysis of Andrographis paniculata and Strobilanthes crispus Chemical Constituens Against Antidiabetic Molecular Targets. Journal of The Indonesian Chemical Society, 02(2): 106-113. https://doi.org/10.34311/jics.2019.02.2.106.

[19]. Rafat, A., Philip, K., \& Muniandy, S. (2010). Antioxidant potential and content of phenolic compounds in ethanolic extracts of selected parts of Andrographis paniculata. Journal of Medicinal Plants Research, 4(2): 197-202. https://doi.org/10.5897/JMPR.9000224.

[20]. Jia, Z., Ye, Q., Dinaut, A. N., Wang, Q., Waddleton, D., Payette, P., ... Taylor, S. D. (2001). Structure of Protein Tyrosine Phosphatase 1B in Complex with 
Inhibitors Bearing Two Phosphotyrosine Mimetics. J. Med. Chem., 44: 45844594. https://doi.org/10.1021/jm010266w.

[21]. Hiriyanna, K. T., Baedke, D., Baek K. H., \& Forney B. A. (1994). Thiophosphorylated substrate analogs are potent active site-directed inhibitors of protein-tyrosine phosphatases. Analytical Biochemistry, 223(1): 51-58. https://doi.org/10.1006/abio.1994.1545.

[22]. Gong, Y., Qin, X., Zhai, Y., Hao, H., Lee, J., \& Park, Y. (2017). Macromolecules Inhibitory effect of hesperetin on $\alpha$-glucosidase: Molecular dynamics simulation integrating inhibition kinetics. International Journal of Biological Macromolecules, 101: 32-39. https://doi.org/10.1016/j.ijbiomac.2017.03.072.

[23]. Deng, D., Sun, P., Yan, C., Ke, M., Jiang, X., Xiong, L., \& Ren, W. (2015). Molecular basis of ligand recognition and transport by glucose transporters. Nature, 526: 391-396. https://doi.org/10.1038/nature14655.

[24]. Pholphana, N., Rangkadilok, N., Thongnest, S., Ruchirawat, S., Ruchirawat, M., \& Satayavivad, J. (2004). Determination and variation of three active diterpenoids in Andrographis paniculata (Burm.f.) Nees. Phytochemical Analysis, 15(6): 365-371. https://doi.org/10.1002/pca.789. 